\title{
Penerapan Metode Question Student Have Untuk Meningkatkan Aktivitas Belajar Peserta Didik
}

\author{
Nurhaswinda \\ Program Studi Pendidikan Guru Sekolah Dasar, Fakultas Ilmu Pendidikan Universitas Pablawan Tuanku \\ Tambusai, Riau \\ e-mail:nurbaswinda01@gmail.com
}

\begin{abstract}
ABSTRAK. The background this research is the low learning activity of students, especially in questioning skills in the learning process. This study aims to determine whether there is an increase in the learning activities of students after applying the question student have method. This research is a Classroom Action Research (CAR). The sample of this research was the fourth grade students of the 2018/2019 academic year with 20 students. This research was completed in 2 cycles consisting of four stages, namely planning, acting, observing, and reflecting. The data collection instruments used were observation and documentation. The results showed that using the question student have method can improve the learning activities of students in mathematics in fourth grade of Elementary School Pahlawan. The activity level of students before the question student have method was applied was $54.28 \%$ in the low category. After applying the question student have method in Cycle I, there was an increase of $61.07 \%$ in the middle category, and in Cycle II there was an increase of $80.72 \%$ in the high category. Based on the results of this study, it can be concluded that the application of the question student have method can improve the learning activities of students in mathematics.
\end{abstract}

Kata kunci: question student have, learning activity, mathematics, classroom action research.

\section{PENDAHULUAN}

Pembelajaran harus dilakukan secara terukur dan terkendali sesuai dengan tujuan yag telah dirumuskan. Seorang guru menentukan apa tujuan yang harus dicapai oleh peserta didik sehingga proses belajar akan berjalan lancar. Belajar mengajar merupakan suatu proses yang mengandung serangkaian perbuatan guru dan peserta didik atas dasar timbal balik yang berlangsung dengan sistem edukatif untuk mencapai tujuan-tujuan tertentu. Interaksi atau hubungan timbal balik antara guru dan peserta didik merupakan syarat utama berlangsungnya proses belajar mengajar (Usman, 2010). Pembelajaran pada hakikatnya adalah untuk menciptakan aktivitas belajar peserta didik secara maksimal. Oleh sebab itu, perlu pemilihan teknik pembelajaran yang tepat dan efesien, sebagaimana yang kita ketahui belajar adalah suatu proses yang dilakukan oleh peserta didik untuk memperoleh 
suatu perubahan tingkah laku yang baru secara keseluruhan, sebagai hasil dari pengalaman peserta didik itu sendiri dalam interaksi dengan lingkungannya (Tohirin, 2007).

Pengamatan proses pembelajaran di kelas dilakukan terlebih dahulu oleh peneliti di salah satu kelas di Sekolah Dasar Pahlawan. Beradasrkan hasil pengamatan, penggunaan metode mengajar yang tidak sesuai atau kurang tepat sangat mempengaruhi aktivitas belajar peserta didik dalam pembelajaran matematika sehingga peserta didik tidak dapat dengan mudah memahami dan menguasai materi yang disampaikan. Di Sekolah Dasar Pahlawan dari studi pendahuluan yang peneliti lakukan, terlihat aktivitas mengikuti pelajaran matematika masih kurang. Hal ini terlihat dari 20 orang peserta didik ada 14 orang $(70 \%)$ peserta didik yang tidak mengerjakan tugas; Dari 20 orang peserta didik ada 15 orang (75\%) peserta didik yang keluar masuk pada saat proses pembelajaran; Dari 20 orang peserta didik ada 16 orang (80\%) peserta didik yang bermain-main dalam proses pembelajaran, serta dari 20 orang peserta didik ada 19 orang $(95 \%)$ peserta didik yang tidak berani mengajukan pertanyaan. Oleh karena itu, supaya kegiatan belajar mengajar mencapai tujuan yang optimal, guru diharapkan memiliki kemampuan-kemampuan yang diperlukan peserta didik, menguasai materi yang akan diajarkan, mampu mengklasifikasikan macammacam metode mengajar dan menguasai teknik-teknik mengajar. Mengganti cara proses belajar mengajar dengan menggunakan bantuan media, pendekatan, metode dan lain-lain sebagai pembantu dalam pemahaman siswa yang belum paham yang diharapkan dapat merubah atau membuat suasana baru dalam proses belajar mengajar (Sari dkk., 2020).

Berdasarkan permasalahan yang terjadi di SD Pahlawan mengenai rendahnya aktivitas peserta didik dalam pembelajaran matematika, peneliti mencoba untuk mengatasi masalah tersebut, yakni dengan penerapan metode question students have sebagai upaya untuk meningkatkan aktivitas peserta didik. Banyak peneliti telah merespon upaya untuk meningkatkan aktivitas belajar peserta didik selama proses pembelajaran, hal ini ditunjukkan dengan banyaknya penelitan yang memfokuskan pada question student have (Erlina, 2019; Sumirat, 2017; Tadius, 2017) terhadap peningkatan aktivitas belajar peserta didik (Handayani, 2020; Nawangsih \& Andriani, 2019). Semua penelitian relevan ini menunjukkan hasil bahwa metode question student have lebih efektif dibandingkan dengan metode diskusi untuk meningkatkan aktivitas belajar peserta didik serta dapat membuat peserta didik termotivasi dalam belajar sehingga peserta didik dapat memahami materi yang diajarkan dan dituntut lebih aktif. Selain menjadikan peserta didik aktif dan termotivasi dalam belajar, kemampuan bertanya merupakan kunci dalam proses pembelajaran (Coutinho \& Almeida, 2014). Guru lebih meningkatkan aktivitasnya pada aspek-aspek yang masih dinilai kurang, dengan memberikan motivasi kepada siswa agar lebih baik dalam pembelajaran (Nurhaswinda, 2019).

Menurut Suprijono (2012), metode pembelajaran question student have merupakan salah satu metode pembelajaran aktif yang dikembangkan untuk melatih peserta didik agar memiliki kemampuan dan keteramplan dalam bertanya. Dengan metode question students have, peserta didik dapat menyampaikan pertanyaan melalui tulisan di dalam kartu indeks kosong yang dapat dilakukan dengan variasi kerja kelompok. Ini merupakan teknik yang mudah untuk mempelajari keinginan dan harapan peserta didik. Dengan penerapan metode tersebut diharapkan dapat meningkatkan aktivitas peserta didik dalam proses pembelajaran matematika, sehingga guru tidak mendominasi proses pembelajaran karena peserta didik dapat berperan aktif. Aktivitas dalam metode belajar aktif tipe question student have ini merupakan salah satu cara yang digunakan untuk mempelajari tentang keinginan 
dan harapan anak didik sebagai dasar untuk memaksimalkan potensi yang mereka miliki (Fitria, 2017).

Supaya kegiatan belajar mengajar mencapai tujuan yang optimal, guru diharapkan memiliki kemampuan-kemampuan yang diperlukan peserta didik, menguasai materi yang akan diajarkan, mampu mengklasifikasikan macam-macam metode mengajar dan menguasai teknik-teknik mengajar. Keberhasilan peserta didik akan banyak bergantung pada metode yang digunakan oleh guru. Maka penentuan metode bagi guru merupakan hal yang cukup penting. Dijelaskan dalam Al-Qur'an surat Al-Ra'd ayat 11, yang artinya "Sesungguhnya Allah tidak merubah keadaan sesuatu kaum sehingga mereka merubah keadaan yang ada pada diri mereka sendiri.....”. Dengan ini telah jelas bahwa dengan menggunakan metode question student have membuat peserta didik melakukan aktivitas karena Allah tidak akan mengubah keadaan peserta didik sehingga mereka sendiri yang mengubah apa yang terdapat pada diri mereka (Shaleh, 2009). Dengan itu supaya peserta didik dapat mengubah keadaan tersebut, digunakanlah metode question student have dalam proses pembelajaran karena metode ini membuat peserta didik menulis pertanyaanpertanyaan di sebuah potongan kertas, maka dengan metode ini akan membuat peserta didik untuk dapat memberanikan diri dalam mengajukan pertanyaan.

Pembelajaran dengan metode question student have dalam matematika akan dapat membantu meningkatkan sikap positif peserta didik didik dalam belajar matematika. Peserta didik didik secara individu akan membangun kepercayaan diri terhadap kemampuan dalam menyelesaikan masalah-masalah matematika. Sehingga akan mengurangi bahkan menghilangkan rasa cemas terhadap matematika. Metode pembelajaran ini juga terbukti sangat bermanfaat bagi para peserta didik didik yang heterogen. Adanya kompetensi antar kelompok belajar juga dapat menumbuhkan aktivitas belajar para Peserta didik didik, lebih percaya diri, sehingga lebih mudah menguasai materi pelajaran matematika. Akibatnya aktivitas belajar matematika akan meningkat (Suherman, 2003). Sebagaimana yang telah diungkapkan oleh Hanifah \& Suhana (2012) bahwa aktivitas belajar dalam proses pembelajaran dapat memberikan nilai tambah (added value) bagi peserta didik (Hanifa \& Suhana, 2009).

Pada penerapan metode question student have aktivitas belajar yang diterapkan adalah aktivitas lisan dan tulisan. Aktivitas belajar peserta didik dapat memberikan nilai tambah bagi peserta didik antara lain dapat menumbuh kembangkan pemahaman dan berpikir kritis, serta berdampak baik pada prestasi belajar peserta didik. Pada saat peserta didik menuliskan dan membuat pertanyaan di kertas kemudian ditukarkan dengan temannya disini terdapat aktivitas verbal dan visual (Nastiti \& Murdiono, 2016).

Selain peserta didik mengajukan pertanyaan, dalam pembelajaran ini diperbolehkan kepada peserta didik mencurahkan keluhan-keluhan, keinginan maupun harapan yang mereka pendam dan yang diinginkan selama mengikuti pelajaran. Hal ini guru akan dapat melihat bagaimana keinginan peserta didik yang sebenarnya dalam mengikuti proses belajar mengajar, yang pada akhirnya akan menimbulkan kegiatan belajar mengajar yang aktif dan terbuka. Berdasarkan latar belakang tersebut, maka peneliti tertarik untuk melakukan penelitian tentang penerapan metode question student have untuk meningkatkan aktivitas belajar peserta didik pada mata pelajaran matematika di Kelas IV Sekolah Dasar Pahlawan. 


\section{METODOLOGI}

Metode yang digunakan adalah penelitian tindakan yang difokuskan pada situasi kelas, atau lazim disebut dengan classroom action research. Penelitian tindakan kelas merupakan penelitian yang dilakukan oleh guru yang subjeknya seluruh siswa di dalam kelas tersebut dengan tujuan untuk memperbaiki atau meningkatkan proses pembelajaran (Marta, 2018; Uno, 2008).Penelitian ini dilaksanakan di kelas IV Sekolah Dasar Pahlawan dengan jumlah peserta didik 20 orang. Mata pelajaran yang akan diteliti adalah mata pelajaran Matematika. Penelitian ini dilaksanakan pada bulan April 2019. Menurut Suharsimi (2010) menyatakan bahwa secara garis besar penelitian tindakan kelas dilaksanakan melalui empat tahap, yaitu: perencanaan, pelaksanaan, pengamatan, dan refleksi. Tahapan-tahapan penelitian tindakan kelas dapat dilihat pada Gambar 1.

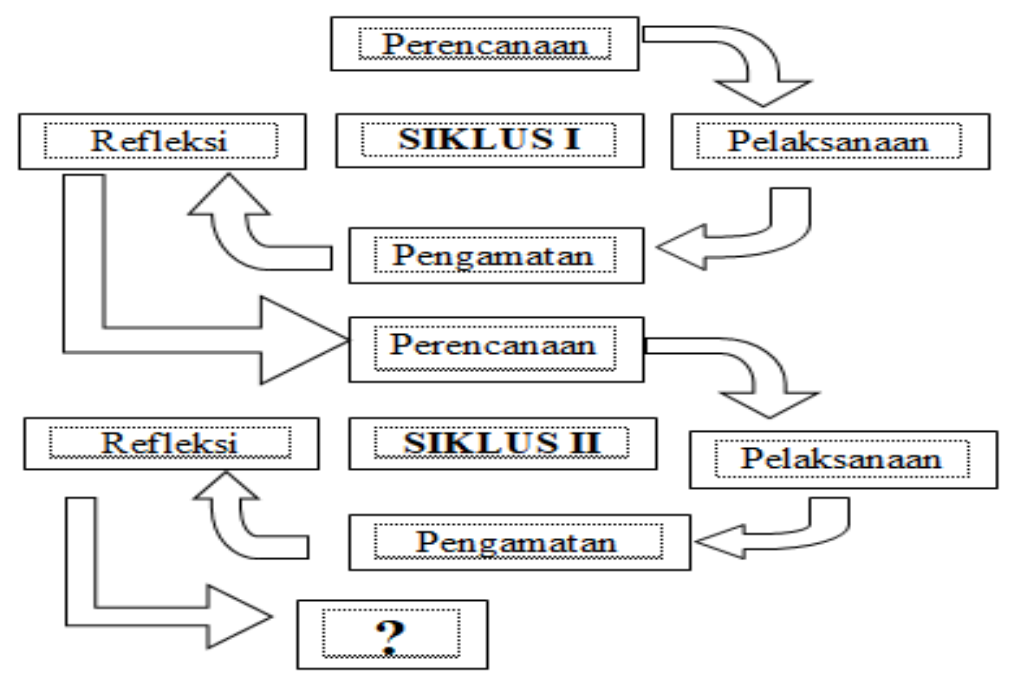

\section{Gambar 1. Siklus Penelitian Tindakan Kelas (PTK)}

Instrumen pengumpulan data dalam penelitian ini adalah observasi dan dokumentasi. Observasi digunakan untuk mengetahui kondisi objektif saat kegiatan belajar mengajar, serta faktor-faktor yang dapat mempengaruhinya. Sedangkan dokumentasi digunakan untuk mencari data melalui peninggalan tertulis seperti arsip dan termasuk juga buku-buku tentang pendapat teori dan lain-lain yang yang berhubungan dengan masalah penelitian (Margono, 2000). Instrumen ini bertujuan untuk memperoleh gambaran langsung tentang aktivitas belajar peserta didik.

Teknik analisa data pada penelitian ini adalah teknik analisis deskriptif. Teknik statistik deskriptif merupakan kegiatan statistik yang mulai dari menghimpunan data, menyusun atau mengukur data, mengolah data, menyajikan dan menganalisis data angka guna memberikan gambaran suatu gejala, peristiwa, atau keadaan. Analisis deskritif ini dilaksanakan untuk mengetahui gambaran data yang akan dianalisis.

Analisis kualitatif, yaitu data yang berupa informasi berbentuk kalimat yang memberi gambaran tentang ekspresi peserta didik berkaitan dengan tingkat pemahaman terhadap suatu mata pelajaran (kongnitatif), pandangan atau sikap peserta didik terhadap teknik belajar yang baru (afektif), aktivitas peserta didik mengikuti pelajaran, perhatian, antusias dalam belajar, kepercayaan diri dan sejenisnya dianlisis secara kualitatif. Analisis data kuantitatif, yaitu data yang berupa angka (nilai hasil belajar peserta didik) dapat 
dianalisis secara deskritif. Misalnya mencari nilai rata-rata, presentase keberhasilan belajar, dan lain-lain. Yang digunakan peneliti adalah dengan cara mengobservasi peserta didik dan guru, observasi aktivitas belajar peserta didik.

Pada lembaran observasi, setiap aktivitas peserta didik dan aktivitas guru diberi kode "1", sedangkan aktivitas peserta didik dan aktivitas guru yang tidak melakukan kegiatan diberi kode " 0 ". Setelah data terkumpul melalui observasi, data tersebut diolah dengan menggunakan rumus persentase (Sudijono, 2004) yaitu sebagai berikut:

$$
\mathrm{P}=\frac{F}{N} \times 100 \%
$$

Keterangan:

F : frekuensi yang sedang dicari persentasenya

$\mathrm{N}$ : number of Cases (jumlah frekuensi/banyaknya individu)

$\mathrm{P}$ : angka persentase

Dalam menentukan kriteria penilaian tentang hasil penelitian, maka dilakukan pengelompokkan atas 4 kriteria penilaian yaitu tinggi, cukup tinggi, kurang tinggi dan tidak tinggi. Interval dan kategori kriteria persentase kegiatan aktivitas peserta didik dapat dilihat pada Tabel 1.

Tabel 1. Kategori kegiatan aktivitas peserta didik dan guru (Sudijono, 2004)

\begin{tabular}{ccc}
\hline No & Interval (\%) & Kategori \\
\hline 1 & $80-100$ & Tinggi \\
2 & $60-79$ & Cukup Tinggi \\
3 & $40-59$ & Kurang Tinggi \\
4 & $0-39$ & Tidak Tinggi \\
\hline
\end{tabular}

\section{TEMUAN DAN DISKUSI}

Metode pembelajaran question student have ialah salah satu cara guru dalam proses pembelajaran untuk menjadikan peserta didik yang aktif sehingga tidak membuat peserta didik takut untuk mempelajari apa yang mereka harapkan dan butuhkan.

\section{Hasil Siklus Pertama}

Pada tahap perencanaan penelitian siklus I, guru terlebih dahulu mempersiapkan perangkat pembelajaran, diantaranya: a) Menyiapkan silabus kelas IV semester 2; b) Menyusun rencana pembelajaran yang berorientasi pada metode question student have; c) Membuat lembar kegiatan peserta didik (LKS); d) Menyiapkan lembar observasi aktivitas peserta didik dan rubrik penilaiannya. Serta membentuk kelompok peserta didik dalam kegiatan belajar. Peserta didik dibentuk menjadi 5 kelompok, masing-masing kelompok terdiri dari 4 peserta didik. Guru meminta peserta didik duduk dalam kelompok-kelompok kecil yang telah ditentukan.

Pada tahap tindakan siklus I, hasil kegiatan pelaksanaan kegiatan pembelajaran pada penelitian tindakan kelas dijelaskan sebagai berikut. (1) Rata-rata persentase indikator aktivitas belajar peserta didik dengan penerapan dalam proses pembelajaran Matematika dengan penerapan metode question student have pada siklus I adalah 61,07\% dengan kategori Cukup Tinggi. (2) Rata-rata persentase aktivitas peserta didik dengan penerapan metode 
question student have pada siklus I adalah 66,57\% atau dengan kategori cukup Tinggi. (3) Pengamatan terhadap aktivitas guru dengan penerapan metode question student bave dilakukan berdasarkan langkah-langkah yang berjumlah 9 aspek. Rata-rata persentase aktivitas guru dengan penerapan metode question student have pada siklus I adalah 61,12\% dengan kategori cukup Tinggi.

Pada tahap pengamatan siklus I, diperoleh hasil bahwa kekurangan aktivitas guru dengan penerapan metode question student have pada siklus I sangat berpengaruh terhadap aktivitas belajar peserta didik. Pada saat siklus I dilaksanakan belum sesuai dengan yang direncanakan, baik aktifitas guru maupun aktivitas peserta didik masih kurang seperti : (1) Guru belum maksimal dalam menerapkan pelaksanaan langkah-langkah question student have dan membimbing peserta didik pada saat mengerjakan LKS; (2) Peserta didik belum terbiasa dengan kondisi belajar metode question student have; (3) Peserta didik belum memahami secara menyeluruh langkah-langkah metode question student have; (4) Masih ada peserta didik yang kurang mampu membuat pertanyaan; dan (5) Masih ada peserta didik yang belum dapat meninjau pertanyaan dari temannya. Menurut Rahmawati (2015) question student have memiliki kekurangan yaitu sering kali pertanyaan peserta didik tidak sesuai dengan topik pelajaran, tetapi strategi ini sangat baik digunakan pada peserta didik yang kurang berani mengungkapkan pertanyaan, keinginan dan harapan-harapannya melalui percakapan (Rahmawati dkk., 2016).

Terakhir, pada tahap refleksi siklus I, disimpulkan bahwa aktivitas belajar peserta didik pada mata pelajaran Matematika dengan penerapan metode question student have pada siklus I berada pada klasifikasi Cukup Tinggi dengan persentase sebesar 61,07\%, namun rata-rata persentase aktivitas belajar peserta didik pada mata pelajaran Matematika belum mencapai standar keberhasilan yang ditetapkan, yaitu 75\%. Tahap refleksi dimaksudkan untuk melihat apakah capaian pada pembelajaran siklus I telah sesuai dengan indikator keberhasilan penelitian yang telah ditetapkan (Handayami, 2020). Penyebab belum tercapainya hasil pembelajaran yang ditentukan dikarenakan karena guru dan peserta didik belum maksimal dalam melaksanakan pembelajaran melalui penerapan metode question student have (Tadius, 2017).

\section{Hasil Siklus Kedua}

Kegiatan pada siklus II hampir sama dengan pelaksanaan pada siklus I, tetapi telah dilakukan perbaikan tindakan yang didasarkan pada hasil refleksi pertama. Kemampuan guru melakukan perbaikan-perbaikan melalui refleksi setelah pertemuan pembelajaran berlangsung merupakan faktor penting agar dapat lebih baik pada pertemuan berikutnya (Erlina, 2019). Dari kesepakatan sebelumnya bahwa guru perlu melakukan perbaikan dan penyempurnaan terhadap aspek-aspek pembelajaran yang belum optimal pada siklus I. Sebelum pembelajaran siklus II dilaksanakan, guru terlebih dahulu membuat perencanaan penyempurnaan aspek-aspek kegiatan pembelajaran yang belum terlaksana dengan optimal, baik menyangkut kegiatan guru maupun kegiatan peserta didik.

Tahap perencanaan penelitian pada siklus II, dirancang berdasarkan hasil refleksi tindakan siklus I. Adapun rencana pelaksanaan siklus II sebagai berikut: 1) Guru lebih meningkatkan aktifitasnya pada aspek-aspek yang masih dinilai kurang, dengan memberikan motivasi kepada peserta didik agar lebih baik dalam pembelajaran; 2) Guru menyampaikan pentingnya metode question student have bagi anak yang kurang berani mengungkapkan pertanyaannya; 3) Meminta peserta didik untuk bekerja sama dalam 
kelompok; 4) Guru menjelaskan lagi langkah-langkah metode question student have; 5) Guru memberikan nasehat kepada peserta didik yang belum meninjau pertanyaan temannya; 6 ) Selain itu guru memberikan solusi, pujian, penghargaan, hadiah, dan sanksi sehingga dapat meningkatkan aktivitas belajar peserta didik.

Pada tahap pelaksanaan tindakan siklus II, peneliti yang bertindak sebagai guru melaksanakan tindakan sesuai dengan langkah-langkah pembelajaran dengan metode question student have seperti pada RPP yang telah disusun. Selama pelaksanaan tindakan berlangsung, peneliti dibantu oleh rekan peneliti dalam melakukan observasi. Observasi dilakukan berdasarkan pedoman observasi yang telah disusun, dan hasilnya dicatat dalam lembar observasi dan catatan lapangan. Penjelasan mengenai hasil tahap pelaksanaan tindakan kegiatan pada siklus II dijelaskan sebagai berikut. (1) Rata-rata persentase aktivitas indikator aktivitas belajar peserta didik dengan penerapan metode question student have dalam proses pembelajaran Matematika pada siklus II adalah 80,72\% dengan kategori Tinggi. (2) Rata-rata persentase aktivitas belajar peserta didik dengan penerapan metode question student have pada siklus II adalah 80,31\% atau dengan kategori Tinggi. (3) Rekapitulasi aktivitas guru melalui metode question student have pada siklus II diperoleh rata-rata persentase 83,34\% dengan kategori Tinggi.

Pada tahap pengamatan siklus II, diperoleh hasil pengamatan kegiatan belajar mengajar sebagai berikut: (1) Kegiatan guru dalam pembelajaran dilihat dari beberapa aspek telah lebih tinggi, seperti pelaksanaan langkah-langkah question studen have dan membimbing peserta didik pada saat mengerjakan LKS; (2) Aktivitas belajar telah meningkat 80,72\% telah melebihi indikator keberhasilan yaitu 75\%; (3) Peserta didik merasa senang dengan kondisi belajar metode question student have; (4) Peserta didik sebagian besar telah mampu membuat pertanyaan dan mampu meninjau pertanyaan temannya. Berdasarkan hasil observasi pada tindakan siklus II kegiatan guru dan peserta didik sudah meningkat, dimana kekurangan-kekurangan yang terjadi pada tindakan siklus I sudah dapat diperbaiki (Tadius, 2017).

Terakhir, pada tahap refleksi siklus II, dapat disimpulkan bahwa secara keseluruhan aktivitas belajar peserta didik pada mata pelajaran Matematika dengan penerapan metode question student have pada siklus II telah berada pada klasifikasi Tinggi dengan persentase sebesar 80,72\%. Untuk itu, peneliti sekaligus sebagai guru tidak perlu melakukan siklus berikutnya, kerena sudah jelas aktivitas belajar peserta didik yang diperoleh telah melebihi indikator keberhasilan yang ditetapkan. Hal tersebut dapat terjadi karena penerapan metode question students have dan hasil yang didapatkan sudah sangat efektif. Oleh karena itu, peneliti melakukan refleksi dan menyelasikan dengan siklus II saja.

Perbandingan antara aktivitas belajar peserta didik sebelum dan sesudah dilakukan tindakan dengan menerapkan metode question student have pada siklus I dan siklus II secara jelas dapat dilihat pada Tabel 2.

Tabel 2. Rekapitulas aktivitas belajar pada mata pelajaran matematika

\begin{tabular}{cccccc}
\hline $\mathbf{N}$ & \multirow{2}{*}{ Siklus } & \multicolumn{2}{c}{ Rata-rata } & \multirow{2}{*}{ Rentang } & Keterangan \\
\cline { 3 - 4 } $\mathbf{0}$ & & Ya & Tidak & & \\
1 & Sebelum Tindakan & $54,28 \%$ & $45,72 \%$ & $40-59 \%$ & Kurang Tinggi \\
2 & Siklus I & $61,07 \%$ & $38,93 \%$ & $60-79 \%$ & Cukup Tinggi \\
3 & Siklus II & $80,72 \%$ & $19,28 \%$ & $80-100 \%$ & Tinggi \\
\hline
\end{tabular}


Berdasarkan Tabel 2, hasil penelitian pada data awal menunjukkan bahwa aktivitas belajar sebelum tindakan yang dilakukan di SD Pahlawan dalam belajar matematika dengan rata-rata persentase $54,28 \%$. Setelah dilakukan tindakan dengan menerapkan metode question student have, ternyata aktivitas peserta didik mengalami peningkatan. Pada siklus I diperoleh rata-rata sebesar 61,07\% yang artinya secara keseluruhan aktivitas belajar peserta didik terjadi peningkatan, selanjutnya pada siklus II terjadi peningkatan dengan rata-rata $80,72 \%$ dengan kategori tinggi. Sebagaimana menurut bahwa peningkatan juga terjadi pada proses pembelajaran yang semakin baik (Sanita dkk., 2020).

Hasil pengamatan aktivitas peserta didik dalam pembelajaran matematika melalui penerapan metode question student have pada peserta didik kelas IV SD Pahlawan menunjukkan bahwa peserta didik aktif dalam pembelajaran baik sebelum dan sesudah pembelajaran, hubungan sosial peserta didik semakin baik, peserta didik dengan guru dan telah memenuhi kriteria aktif karena sesuai dengan indikator aktivitas peserta didik, bahwa aktivitas peserta didik dikatakan berhasil/efektif jika sekurang-kurangnya 75\% peserta didik terlibat aktif dalam proses pembelajaran. Sedangkan hasil analisis data observasi aktivitas peserta didik menunjukkan rata-rata persentase aktivitas peserta didik dalam pembelajaran matematika dengan metode question student have yaitu $80,72 \%$. Hal ini dapat disimpulkan bahwa peserta didik sudah aktif mengikuti proses pembelajaran matematika melalui penerapan metode question student have.

Peningkatan rata-rata aktivitas belajar peserta didik pada sebelum tindakan, siklus I, dan siklus II juga dapat dilihat pada Gambar 2.

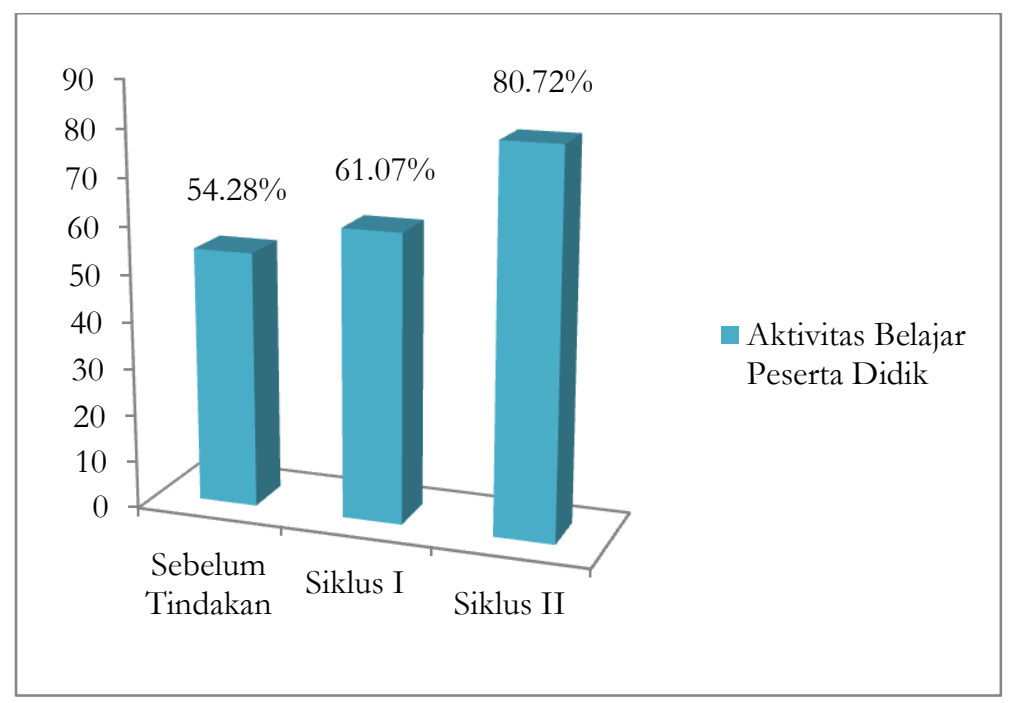

Gambar 2. Grafik peningkatan rata-rata aktivitas belajar peserta didik

Setelah melihat rekapitulasi aktivitas belajar pada mata pelajaran matematika dan dari Gambar di atas, dapat diketahui bahwa aktivitas belajar peserta didik telah mencapai indikator keberhasilan yang telah ditetapkan, yaitu 75\%. Untuk itu, peneliti tidak perlu melakukan siklus berikutnya karena sudah jelas aktivitas belajar peserta didik pada bidang studi matematika yang diperoleh telah meningkat. Pencapaian keberhasilan belajar ini tidak lepas dari usaha guru dalam memotivasi peserta didik untuk bisa lebih antusiasi dan terlibat dalam setiap pertemuan. Selain itu, guru juga mampu melaksanakan dengan baik setiap proses dan langkah-langkah pembelajaran yang berorientasi kepada metode pembelajaran yang diterapkan (Erlina, 2019). 
Berdasarkan teori dari Suyadi (2013) bahwa benar adanya dengan membagi peserta didik menjadi beberapa kelompok dan dengan menerapkan metode question student have dapat melatih kemampuan bekerja sama antar peserta didik sehingga sulit bagi peserta didik untuk tidak aktif dalam proses pembelajaran. Biasanya peserta didik hanya bekerja sendiri dalam mengerjakan tugas kelompok yang diberikan namun dengan metode question student have, peserta didik dengan mudah saling bekerja sama dalam mengerjakan tugas. Penelitian serupa juga dilakukan Nawangsih \& Andriani (2019) menunjukkan bahwa dengan menerapkan metode question student have dapat meningkatkan aktivitas belajar peserta didik pada mata pelajaran Ilmu Pengetahuan Alam. Begitu pula dengan hasil penelitian menurut Nastiti (2016) dan Ilyas (2013) menunjukkan bahwa metode question student have lebih efektif dibandingkan dengan metode diskusi untuk meningkatkan aktivitas belajar peserta didik.

Metode question student have dapat melatih kemampuan peserta didik dalam mendengarkan pendapat teman-teman sekelasnya tanpa adanya keinginan untuk saling menang sendiri. Serta, dengan metode question student have menambah pengetahuan peserta didik terhadap materi yang dipelajari karena banyaknya pendapat dan masukan dari temanteman lainnya. Kelebihan lainnya dengan menerapkan metode question student have dapat melatih rasa peduli dan kerelaan untuk berbagi di dalam mengerjakan tugas yang diberikan guru, serta tertib dalam menjawab pertanyaan yang diberikan guru dan dari peserta didikpeserta didik lainnya dan dapat meningkatkan minat, aktivitas dan suasana belajar serta kecepatan menangkap materi yang diberikan oleh guru sehingga proses pembelajaran yang diharapkan dapat berjalan dengan lancar.

\section{KESIMPULAN}

Disimpulkan bahwa penerapan metode question student have dapat meningkatkan aktivitas belajar peserta didik pada mata pelajaran matematika di kelas IV Sekolah Dasar Pahlawan. Terlihat dari sebelum tindakan aktivitas belajar yang dilakukan di SD Negeri Pahlawan dalam belajar matematika dengan rata-rata persentase $54,28 \%$ berada pada kategori kurang tinggi yang berada pada rentang 40-59\%. Setelah dilakukan tindakan perbaikan ternyata aktivitas peserta didik meningkat yaitu pada siklus I dengan rata-rata $61,07 \%$ artinya secara keseluruhan aktivitas belajar terjadi peningkatan, berada pada kategori cukup tinggi yang berada pada rentang 60-79\%, selanjutnya pada siklus II terjadi peningkatan dengan ratarata $80,72 \%$ berada pada kategori maksimal atau tinggi yang berada pada rentang 80 $100 \%$. Artinya keberhasilan peserta didik dengan diterapkannya metode question student have telah mencapai indikator keberhasilan yang telah ditetapkan yaitu 75\%.

\section{PENGHARGAAN}

Penulis mengucapkan terima kasih kepada Rektor Universitas Pahlawan Tuanku Tambusai dan Dekan Fakultas Ilmu Pendidikan serta para dosen yang telah memfasilitasi peneliti dalam menggunakan sampel penelitian ini, dan kepada semua pihak yang telah memberikan banyak saran berharga dalam penelitian ini. 


\section{REFERENSI}

Coutinho, M. J., \& Almeida, P. A. (2014). Promoting student questioning in the learning of natural sciences. Procedia-Social and Behavioral Sciences, 116, 3781-3785.

Erlina, E. (2019). Penerapan Metode Question Student Have dalam Upaya Peningkatan Keaktifan dan Hasil Belajar Siswa pada Pembelajaran Konsep Virus Di MAN 4 Pidie. Jurnal Sosial Humaniora Sigli, 2(1), 88-100.

Fitria, Y. (2017). Upaya Meningkatkan Hasil Belajar Peserta didik dalam Mata Pelajaran Matematika melalui Model Pembelajaran Question Student Have (QSH) pada Siswa Kelas VIII. 1 SMP N 1 Sasak Ranah Pasisie. Jurnal Manajemen Pendidikan, 2(1).

Hanafiah, N., \& Suhana, C. (2009). Konsep Strategi Pembelajaran. Bandung: Refika Aditama.

Handayani, W. (2020). Upaya Meningkatkan Aktivitas dan Hasil Belajar Matematika Dengan Model Question Student Have Pada Siswa Kelas XII-IPA-3 SMA Negeri 1 Tapen Kab. Bondowoso Tahun Pelajaran 2017/2018. Jurnal Refleksi Pembelajaran (JRP), 5(1), 31-40.

Ilyas, dkk. (2013).Pengaruh penerapan strategi pembelajaran aktif tipe Question Student Have terhadap pemahaman konsep matematis pesekerta didik Kelas VII SMP Pertiwi Padang. Jurnal Bung Hatta, 2(1), 1-11.

Margono, S. (2000). Metodologi Penelitian Pendidikan. Jakarta: Rineka Cipta.

Marta, R. (2018). Penerapan Model Kooperatif Tipe Nominal Group untuk Meningkatkan Hasil Belajar Matematika Di Kelas IV Sekolah Dasar. Jurnal Basicedu, 2(1), 77-86.

Nastiti, D. \& Murdiono, M. (2016). Efektivitas Penerapan Metode Question Student Have terhadap Aktivitas dan Prestasi Belajar Siswa dalam Pembelajaran Pendidikan Kewarganegaraan. Jurnal Pendidikan Kewarganegaraan dan Hukum, 1-10.

Nawangsih, I., \& Andriani, M. (2019). Penerapan Metode Question Student Have Untuk Meningkatkan Aktivitas Belajar Siswa pada Mata Pelajaran Ilmu Pengetahuan Alam Di Kelas V Sekolah Dasar Negeri 006 Sungai Buluh Kecamatan Singingi Hilir Kabupaten Kuantan Singingi. el-Ibtidaiy: Journal of Primary Education, 2(2), 93-105.

Nurhaswinda,. (2019) Peningkatan pemahaman konsep perkalian berbantuan kalkulator pada mata pelajaran matematika di kelas IV sekolah dasar negeri 2. Jurnal Basicedu 3 (2), 422-427.

Rahmawati, L., Rahayu, E. S., \& HB, F. P. M. (2016). Pengaruh Penggunaan Strategi Question Student Have (QSH), Media Interaktif Ekosistem, dan Kombinasinya Terhadap Hasil Belajar Siswa. Journal of Biology Education, 5(1).

Sanita, S., Marta, R., \& Nurhaswinda, N. (2020). Peningkatan Kemampuan Menulis Karangan Deskripsi dengan Metode Pembelajaran Field Trip. Journal on Teacher Education, 2(1), 239-246.

Sari, N., Daulay, M. I., \& Nurhaswinda, N. (2020). Peningkatan Kemampuan Membaca Permulaan Menggunakan Metode Struktur Analisis Sintesis (SAS) Di Sekolah Dasar. Journal on Teacher Education, 2(2), 231-238.

Shaleh, A. R. (2009). Psikologi: Suatu Pengantar Dalam Perspektif Islam. Jakarta: Kencana Prenada Media Group.

Sudijono, A. (2004). Pengantar Statistik Pendidikan. Jakarta: Raja Grafindo Persada. 
Suharsimi, A. (2010). Prosedur Penelitian Suatu Pendekatan Praktik. Jakarta: Rineka Cipta.

Suherman, E. (2003). Strategi Pembelajaran Matematika Kontemporer. Bandung: Jica.

Sumirat, J. (2017). Penerapan Model Pembelajaran Kooperatif Tipe Question Students Have Untuk Meningkatkan Kemampuan Kerjasama Siswa Di Sekolah Dasar. Jurnal Pendidikan Guru Sekolah Dasar, 1(1), 122-130.

Suprijono, A. (2012). Cooperative Learning: Teori \& Aplikasi PAIKEM. Yogyakarta: Pustaka Pelajar.

Suyadi. (2013). Strategi Pembelajaran Pendidikan Karakter. Bandung: PT Remaja Rosdakarya.

Tadius, M. P. (2017). Penerapan Metode Question Student Have Dalam Meningkatkan Hasil Belajar IPA Siswa Kelas IV SDN 139 Tampapute Kecamatan Gandangbatu Sillanan Kabupaten Tana Toraja. Jurnal Keguruan dan Ilmu Pendidikan, 6(2), 1539-1548.

Tohirin. (2007). Psikologi Pembelajaran Pendidikan Agama Islam. Jakarta: Raja Grafindo Persada.

Uno, H. B. (2008). Perencanaan Pembelajaran. Jakarta: Bumi Aksara.

Usman. (2010). Menjadi Guru Profesional. Bandung: Rosda Karya. 